PERM JOURNAL OF PETROLEUM AND MINING ENGINEERING

ВЕСТНИК ПНИПУ. ГЕОЛОГИЯ. НЕФТЕТАЗОВОЕ И ГОРНОЕ ДЕЛО

ISSN 2224-9923

Volume / Том 20 №1 2020

http://vestnik.pstu.ru/ge

UDC 622.276+553.982.239(470.53)

Article / Статья

(C) PNRPU / ПНИПУ, 2020

\title{
ACID TREATMENT OF CARBONATE DEPOSITS AT THE PERM REGION OIL FIELDS
}

\author{
Vladimir A. Novikov, Dmitry A. Martyushev
}

Perm National Research Polytechnic University (29 Komsomolskiy av., Perm, 614990, Russian Federation)

\section{ОПЫТ ПРИМЕНЕНИЯ КИСЛОТНЫХ СОСТАВОВ В КАРБОНАТНЫХ ОТЛОЖЕНИЯХ НЕФТЯНЫХ МЕСТОРОЖДЕНИЙ ПЕРМСКОГО КРАЯ}

\section{В.А. Новиков, Д.А. Мартюшев}

Пермский национальный исследовательский политехнический университет (614990, Россия, г. Пермь, Комсомольский проспект, 29)

Received / Получена: 15.07.2019. Accepted / Принята: 10.01.2020. Published / Опубликована: 02.03.2020

Key words:

acid treatment, carbonate reservoir, hydrochloric acid, acid composition, Perm Region fields, acid treatment efficiency, X-ray tomography, void structure, carbonate content, insoluble residue, successful acid treatments, hydrodynamic research, productivity index, bottomhole zone permeability, farfield zone permeability.

\begin{abstract}
Acid treatments are among the most common methods to enhance deliverability of productive wells running on carbonate deposits. Such treatment at the oil fields of OOO LUKOIL-Perm, which are conventionally divided into the Southern, Northern and Nozhovskaya groups depending on their location in the the Perm Region, is complicated by the particular features of the deposit geology, difference in the mineralogical composition of rocks, and properties of formation fluids. To determine the optimal formulation for acid treatment of carbonate deposits for each group of fields, the field application of three most used compositions: DN-9010, FLUXOCORE-210 and NPS-K, was reviewed. During the research, the particular features of the reservoir void structure were studied using X-ray tomography, the mineralogical composition of rocks was determined using KM-04M carbonate metering device, the proportion of successful treatment jobs with each of the acid composition was identified and their efficiency was assessed based on changes in well productivity and the reservoir flow parameters after treatments, obtained from the interpretation of hydrodynamic research data. As a result of the field data analysis, it was established that the number of jobs resulting in the target oil production growth using FLUXOCORE-210 and NPS-K compositions in carbonate sediments of the Southern, Northern and Nozhovskaya oil field groups slightly exceeded the number of successful acid treatments using DN-9010 composition, which was confirmed by hydrodynamic research data where the highest efficiency of NPS-K and FLUXOCORE -210 was identified in comparison with DN-9010. The highest efficiency of NPS-K acid composition was observed at carbonate deposits of Southern and Nozhovskaya groups of fields, while FLUXOCORE -210 showed the best results in the deposits of Northern group of fields.
\end{abstract}

Кислотные обработки являются одним из наиболее распространенных методов повышения продуктивности добывающих скважин, эксплуатирующих карбонатные отложения. Проведение данного рода мероприятий на нефтяных месторождениях ООО «ЛУКОЙЛ-ПЕРМЬ», условно подразделяющихся на Южную, Северную и Ножовскую группы в зависимости от расположения на территории Пермского края, осложняется особенностями геологического строения залежей, различием минералогического состава горных пород и свойств пластовых флюидов. С целью определения наиболее оптимальной рецептуры для кислотного воздействия на карбонатные отложения каждой группы месторождений рассмотрен промысловый опыт применения трех наиболее используемых композиций - ДН-9010, ФЛАКСОКОР-210 и НПС-К. В ходе работы изучены особенности структуры пустотного пространства коллекторов с помощью методов рентгеновской томографии, определен минералогический состав горных пород с помощью карбонатомера КМ-04М, выделена доля успешных мероприятий с каждым из кислотных составов и проведена оценка их эффективности на основании изменения продуктивности скважин и фильтрационных параметров пласта после обработок, полученных при интерпретации материалов гидродинамических исследований. В результате анализа промысловых данных установлено, что количество мероприятий, достигнувших планового прироста дебита нефти, с композициями ФЛАКСОКОР-210 и НПС-К в карбонатных отложениях Южной, Северной и Ножовской групп месторождений несколько превышает количество успешных кислотных обработок составом ДН-9010, что подтверждается данными гидродинамических исследований, где также выделена наибольшая эффективность композиций НПС-К и ФЛАКСОКОР-210 по сравнению с ДН-9010. Наибольшая эффективность кислотного состава НПС-К отмечена на карбонатных залежах Южной и Ножовской групп месторождений, в то время как композиция ФЛАКСОКОР-210 демонстрирует лучшие результаты в отложениях Северной группы месторождений.

Vladimir A. Novikov - MSc student at the Department of Oil and Gas Technologies (tel.: +007 342219 82 50, e-mail: novikov.vladimir.andr@gmail.com).

Dmitry A. Martyushev (Author ID in Scopus: 56308102400) - PhD in Engineering, Associate Professor at the Department of Oil and Gas Technologies (tel.: +007 342 219 82 50, e-mail: martyushevd@inbox.ru). The contact person for correspondance.

Новиков Владимир Андреевич - магистрант кафедры нефтегазовых технологий (тел.: +007 34221982 50, e-mail: novikov.vladimir.andr@gmail.com). Мартюшев Дмитрий Александрович - кандидат технических наук, доцент кафедры нефтегазовых технологий (тел.: +007 3422198250, e-mail: martyushevd@inbox.ru). Контактное лицо для переписки. 


\section{Introduction}

There is a global tendency of decline in oil production from terrigenous reservoirs, which results in the increased bringing into development of hard-to-recover reserves mostly located at carbonate deposits. To improve the efficiency of oil field development in these conditions, various measures are taken to enhance the deliverability of productive wells and to increase the rate of recoverable reserves production [1-5].

Acid treatment is one of the most commonly used methods of flow stimulation in carbonate deposits. It is a method of oil production stimulation, which is based on the increase of existing inflow channels and creation of new ones through rock dissolution by acid [6-11].

Carbonate minerals actively interact with most inorganic and organic acids. Hydrochloric acid solutions with a concentration of 10-15\% wt are normally used for acid treatments, due to its high solvency, bulk production and low cost $[12,13]$.

However, application of pure hydrochloric acid can be affected by the increase in the field equipment corrosion rate and the wellbore damage by reaction products, as well as formation of stable oil emulsions [14-18]. In this respect, hydrochloric-acid-based complex compositions with a range of special additives, including retarders, stabilizers, corrosion inhibitors and solvents for the acid treatment of productive formations, have got widespread use in the oil industry $[19,20]$.

Selection of optimal acid composition is the principal task in planning successful acid treatments [21-25]. Positive result of acid treatment directly relies on the compliance of the selected composition with the geological and physical features of the deposit, including thermodynamic conditions and mineralogical composition of treated rocks and saturating fluids [26-30].

This research examines the field application experience of the acid compositions most commonly used in the Perm Region for the treatment of bottomhole zones of productive wells in order to enhance their deliverability: DN-9010 (NPP Devon, Kazan), FLUXOCORE-210 (AO Polyex, Perm) and NPS-K (OOO NefteProm
Service, Perm) in carbonate deposits of Southern (Vereiskian, Bashkirian (Bashkirian-Serpukhovian), Tournaisian deposits), Northern (BashkirianSerpukhovian, Tournaisian (Tournaisian-Famennian) deposits) and Nozhovskaya (Tournaisian deposits) field groups.

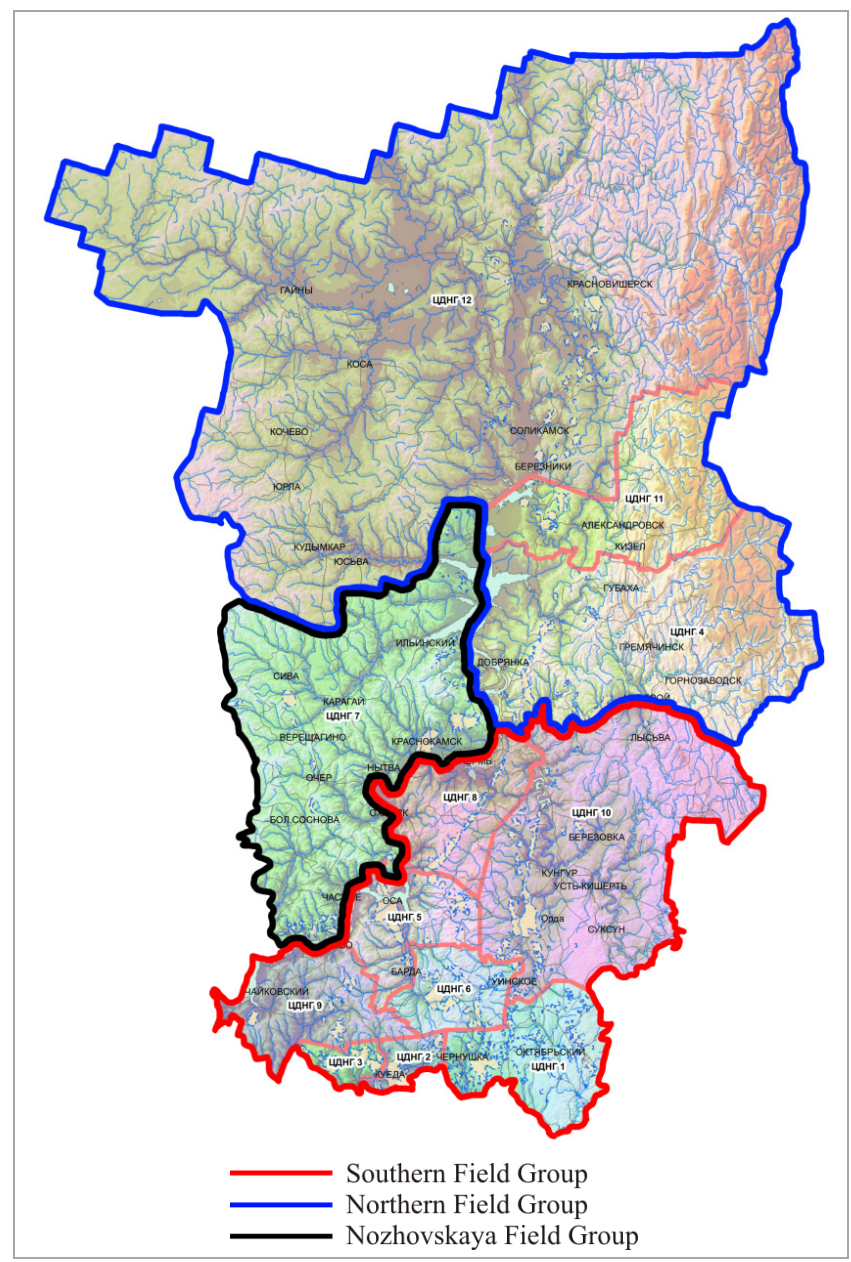

Fig. 1. Boundaries of field groups on the map of Perm Region

\section{Geological and Physical Features of Carbonate Deposits in Perm Region}

Most oil fields in the Perm Region are being developed by OOO LUKOIL-PERM. They can be conventionally divided into three large groups Southern, Northern and Nozhovskaya, with their boundaries shown in Fig. 1.

Geological and physical characteristics of carbonate deposits of the Southern (SFG), Northern (NFG) and Nozhovskaya (NoFG) field groups are given in Table 1 . 
Geological and Physical Characteristics of Carbonate Deposits at SFG, NFG and NoFG

\begin{tabular}{|l|c|c|c|c|c|c|c|}
\hline \multirow{2}{*}{ Parameter } & \multicolumn{3}{|c|}{$\mathrm{SFG}$} & \multicolumn{3}{c|}{ NFG } & NoFG \\
\cline { 2 - 8 } & $\mathrm{C}_{2} \mathrm{vr}$ & $\mathrm{C}_{2} \mathrm{~b}\left(\mathrm{C}_{2} \mathrm{~b}-\mathrm{C}_{1} \mathrm{~s}\right)$ & $\mathrm{C}_{1} \mathrm{t}$ & $\mathrm{C} 2 \mathrm{~b}-\mathrm{C} 1 \mathrm{~s}$ & $\mathrm{C} 1 \mathrm{t}(\mathrm{C} 1 \mathrm{t}-\mathrm{D} 3 \mathrm{fm})$ & $\mathrm{D} 3 \mathrm{fm}$ & $\mathrm{C} 1 \mathrm{t}$ \\
\hline Average Deposit Depth, $\mathrm{m}$ & $\frac{832-1269}{1039}$ & $\frac{853-1500}{1200}$ & $\frac{1327-1816}{1587}$ & $\frac{1267-1853}{1617}$ & $\frac{1603-2270}{1997}$ & $\frac{1997-2001}{1999}$ & $\frac{1390-1685}{1568}$ \\
\hline $\begin{array}{l}\text { Initial Formation Pressure, } \\
\mathrm{MPa}\end{array}$ & $\frac{9,8-15,6}{11,4}$ & $\frac{10,2-16,2}{12,3}$ & $\frac{14,0-19,4}{16,6}$ & $\frac{13,7-21,3}{18,1}$ & $\frac{17,2-26,2}{22,7}$ & $\frac{18,2-20,7}{19,5}$ & $\frac{16,3-16,9}{16,6}$ \\
\hline $\begin{array}{l}\text { Oil Bubble Point Pressure, } \\
\mathrm{MPa}\end{array}$ & $\frac{5,3-9,5}{7,7}$ & $\frac{5,1-12,8}{9,1}$ & $\frac{5,1-15,1}{10,8}$ & $\frac{10,6-17,3}{14,1}$ & $\frac{11,5-16,5}{14,5}$ & $\frac{11,0-14,4}{12,7}$ & $\frac{8,6-12,1}{9,9}$ \\
\hline Gas Content, $\mathrm{m}^{3} / \mathrm{t}$ & $\frac{9,8-78,5}{33,1}$ & $\frac{9,9-107,0}{40,7}$ & $\frac{15,8-138,0}{73,1}$ & $\frac{44,9-201,3}{102,6}$ & $\frac{63,6-291,6}{134,9}$ & $\frac{141,0-185,6}{163,3}$ & $\frac{6,6-14,4}{9,1}$ \\
\hline $\begin{array}{l}\text { Reservoir Oil Viscosity, } \\
\mathrm{mPa} \cdot \mathrm{s}\end{array}$ & $\frac{2,4-29,9}{9,0}$ & $\frac{1,4-34,7}{13,1}$ & $\frac{1,2-68,9}{11,4}$ & $\frac{0,9-10,9}{2,3}$ & $\frac{0,7-4,0}{1,5}$ & $\frac{1,1-1,3}{1,2}$ & $\frac{38,6-87,5}{63,8}$ \\
\hline Paraffin Content, \% & $\frac{2,8-4,9}{3,9}$ & $\frac{2,4-5,4}{3,9}$ & $\frac{1,5-4,6}{3,2}$ & $\frac{2,7-5,4}{4,0}$ & $\frac{3,0-6,0}{4,6}$ & $\frac{3,9-4,6}{4,2}$ & $\frac{1,9-4,0}{3,0}$ \\
\hline Porosity, \% & $\frac{13,0-19,0}{15,5}$ & $\frac{12,0-19,0}{14,6}$ & $\frac{10,0-15,0}{12,2}$ & $\frac{10,0-16,0}{12,4}$ & $\frac{8,0-12,0}{9,7}$ & $\frac{9,0-11,0}{10,0}$ & $\frac{14,0-18,0}{15,4}$ \\
\hline Permeability, $\mu m^{2}$ & $\frac{0,016-0,438}{0,105}$ & $\frac{0,016-0,497}{0,090}$ & $\frac{0,003-0,655}{0,093}$ & $\frac{0,008-0,078}{0,037}$ & $\frac{0,004-0,117}{0,032}$ & $\frac{0,029-0,039}{0,034}$ & $\frac{0,032-0,706}{0,224}$ \\
\hline Compartmentalization, units & $\frac{0,5-5,3}{3,4}$ & $\frac{0,2-16,1}{5,4}$ & $\frac{0,4-21,0}{8,1}$ & $\frac{4,1-21,4}{11,7}$ & $\frac{1,8-26,6}{8,3}$ & $\frac{19,8-24,2}{22,0}$ & $\frac{3,6-8,3}{6,2}$ \\
\hline
\end{tabular}

$\mathrm{N}$ o t e : numerator is a range of indicator values; denominator is a mean value.

The deposits feature a complicated geology structure, with a significant compartmentalization of the section and rather low permeability. The SFG oils are paraffin oils, with high viscosity and medium and high gas content, the NFG ones are paraffin oils with low viscosity and high gas content, and the NoFG ones are paraffin oils with high viscosity and low gas content.

Carbonate reservoirs of the Perm Region have different structure of void space [31], which can be studied using X-ray tomography methods [32-37]. Three-dimensional models of the void space structure of core samples are given in Fig. 2.

Based on the conducted studies it was determined that in the southern part of the region, there is a predominance of pore structure without distinct vugs and fractures (Fig. 2,a). In the northern part of the region, the structure of the void space is more complex, with zones of natural fracturing and vuggy porosity (Fig. 2, b), micro-fracturing (Fig. 2, c), uniform (Fig. 2, d) and non-uniform porosity (Fig. 2,e).

Carbonate content is an essential parameter directly affecting the acidizing efficiency and characterizing the content of carbonate salts, such as calcite and dolomite, in the rock [38]. To determine the content of carbonate minerals in the rocks of the
SFG and the NFG, laboratory tests were carried out using a special carbonate metering device KM-04M (Table 2). The rocks of the Tournaisian (TournaisianFamennian) and Famennian stages of the NFG and the NoFG were not studied in the absence of samples. The description of core samples in the field development design and engineering documentation indicates that deposits of the Tournaisian stage (as in the case of Nozhovskoye field) are represented by algal/lumpy and organogenic/detritic limestones, and of the Tournaisian-Famennian and Famennian stage (as in the case of Unvinskoye and Gagarinskoye fields) - by detritic/lumpy and clastic limestone with a negligible amount of dolomite.

The carbonate deposits of the SFG feature a significant content of insoluble residue represented by argillites, quartz and siltstones, which is a factor reducing the efficiency of acid treatments. The carbonate content in the Tournaisian deposits is generally higher than that of the Bashkirian (Bashkirian-Serpukhovian) and Vereiskian deposits. In the NFG carbonate deposits, a high content of calcite is identified, while dolomite prevails in the rock formation of the Bashkirian deposit of the Ozyornoye field, which complicates the acid treatment process $[39,40]$. 


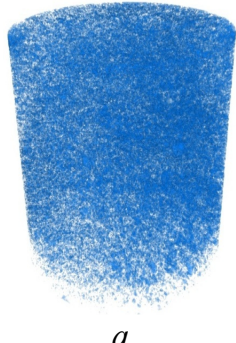

$a$

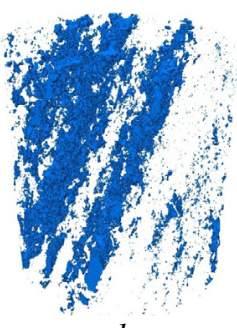

$b$

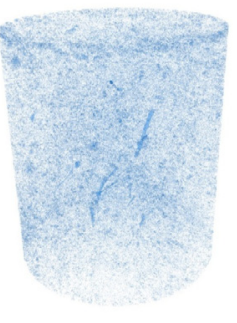

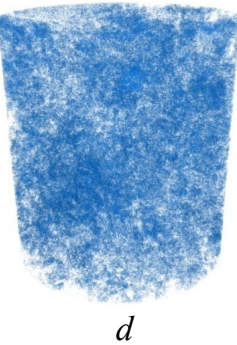

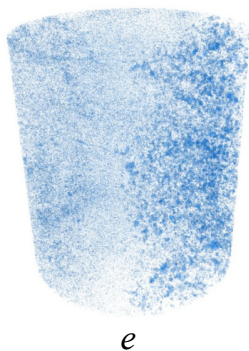

Fig. 2. Structure of void space of carbonate reservoirs in the Perm Region: $a$ - pore structure of the southern part of the region (as illustrated by Osinskoye field); $b$ - fracturing and vuggy porosity (as illustrated by Gagarinskoye field); $c$ - micro-fracturing (as illustrated by Ozyornoye field); $d$ - uniform porosity (as illustrated by Magovskoye field); $e$ - non-uniform porosity (as illustrated by Unvinskoye field)

Table 2

Rock Carbonate Content at Oil Fields in the Perm Region

\begin{tabular}{|c|c|c|c|c|}
\hline \multirow{2}{*}{ Field } & \multirow{2}{*}{ Deposit } & \multicolumn{3}{|c|}{ Component Content, \% } \\
\hline & & Calcite & Dolomite & Insoluble Residue \\
\hline \multicolumn{5}{|c|}{ SFG } \\
\hline Baklanovskoye & $\mathrm{C}_{2} \mathrm{~b}$ & 57.3 & 2.7 & 40.0 \\
\hline Batyrbayskoye & $\mathrm{C}_{2} \mathrm{~b}$ & 56.1 & 2.9 & 41.0 \\
\hline Dorokhovskoye & $\mathrm{C}_{1} \mathrm{t}$ & 96.2 & 0.3 & 3.5 \\
\hline \multirow{2}{*}{ Ilyichevskoye } & $\mathrm{C}_{2} \mathrm{~b}$ & 60.3 & 0.1 & 39.6 \\
\hline & $\mathrm{C}_{2} \mathrm{vr}$ & 89.3 & 0.0 & 10.7 \\
\hline Kazakovskoye & $\mathrm{C}_{1} \mathrm{t}$ & 84.1 & 5.0 & 10.9 \\
\hline \multirow{2}{*}{ Kokuyskoye } & $\mathrm{C}_{2} \mathrm{~b}$ & 88.8 & 0.0 & 11.2 \\
\hline & $\mathrm{C}_{1} \mathrm{t}$ & 89.7 & 0.0 & 10.3 \\
\hline Moskudyinskoye & $\mathrm{C}_{2} \mathrm{vr}$ & 43.6 & 2.3 & 54.1 \\
\hline Osinskoye & $\mathrm{C}_{2} \mathrm{~b}-\mathrm{C}_{1} \mathrm{~s}$ & 55.2 & 2.5 & 42.3 \\
\hline \multirow{2}{*}{ Pavlovskoye } & $\mathrm{C}_{2} \mathrm{~b}$ & 87.1 & 4.1 & 8.8 \\
\hline & $\mathrm{C}_{1} \mathrm{t}$ & 89.8 & 2.8 & 7.4 \\
\hline Sosnovskoye & $\mathrm{C}_{1} \mathrm{t}$ & 97.9 & 0.0 & 2.1 \\
\hline Chaykinskoye & $\mathrm{C}_{1} \mathrm{t}$ & 91.1 & 0.0 & 8.9 \\
\hline \multirow{2}{*}{ Churakovskoye } & $\mathrm{C}_{2} \mathrm{~b}$ & 86.0 & 0.0 & 14.0 \\
\hline & $\mathrm{C}_{1} \mathrm{t}$ & 85.4 & 0.0 & 14.6 \\
\hline Shumovskoye & $\mathrm{C}_{2} \mathrm{~b}$ & 52.1 & 2.1 & 45.8 \\
\hline \multicolumn{5}{|c|}{ NFG } \\
\hline Gagarinskoye & $\mathrm{C}_{2} \mathrm{~b}-\mathrm{C}_{1} \mathrm{~s}$ & 86.5 & 9.2 & 4.2 \\
\hline Magovskoye & $\mathrm{C}_{2} \mathrm{~b}-\mathrm{C}_{1} \mathrm{~s}$ & 87.1 & 1.3 & 11.6 \\
\hline Ozyornoye & $\mathrm{C}_{2} \mathrm{~b}-\mathrm{C}_{1} \mathrm{~s}$ & 10.8 & 77.1 & 12.1 \\
\hline Sibirskoye & $\mathrm{C}_{2} \mathrm{~b}-\mathrm{C}_{1} \mathrm{~s}$ & 92.3 & 0.4 & 7.3 \\
\hline Unvinskoye & $\mathrm{C}_{2} \mathrm{~b}-\mathrm{C}_{1} \mathrm{~s}$ & 89.5 & 0.7 & 9.8 \\
\hline Yurchukskoye & $\mathrm{C}_{2} \mathrm{~b}-\mathrm{C}_{1} \mathrm{~s}$ & 93.7 & 1.3 & 5.0 \\
\hline
\end{tabular}




\section{Application of DN-9010, FLUXOCORE -210 and NPS-K Acid Compositions}

The data on 476 acid treatments with DN-9010, FLUXOCORE -210 and NPS-K compositions at the Vereiskian, Bashkirian (Bashkirian-Serpukhovian), Tournaisian (Tournaisian-Famennian) and Famennian deposits of the Perm Region fields were accepted for research. The formulation of the acid compositions under study is given in Fig. 3.

All the acid compositions contain surfactants that provide high permeability of acids in the productive layer due to a significant drop in the rate of interaction with the rock, and effective inhibitors of hydrochloric acid corrosiveness, which reduce its negative impact on oilfield equipment.

\begin{tabular}{|c|c|c|}
\hline DN-9010 & FLUXOCORE -210 & NPS-K \\
\hline$\perp$ & $\perp$ & L \\
\hline $\begin{array}{l}\text { Hydrochloric acid } \\
\text { aqueous solution }\end{array}$ & $\begin{array}{l}\text { Hydrochloric acid } \\
\text { aqueous solution }\end{array}$ & $\begin{array}{l}\text { Hydrochloric acid } \\
\text { aqueous solution }\end{array}$ \\
\hline I & I & I \\
\hline $\begin{array}{l}\text { Corrosion } \\
\text { inhibitor }\end{array}$ & $\begin{array}{l}\text { Corrosion } \\
\text { inhibitor }\end{array}$ & $\begin{array}{l}\text { Corrosion } \\
\text { inhibitor }\end{array}$ \\
\hline$\perp$ & $\perp$ & $\perp$ \\
\hline Surfactant & Surfactant & Surfactant \\
\hline 1 & 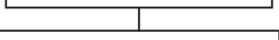 & \begin{tabular}{l|l} 
& 1 \\
\end{tabular} \\
\hline Solvent & $\begin{array}{l}\text { Other high-efficiency } \\
\text { targeted additives }\end{array}$ & $\begin{array}{c}\text { Iron } \\
\text { stabilizer }\end{array}$ \\
\hline
\end{tabular}

Fig. 3. Formulation of acid compositions

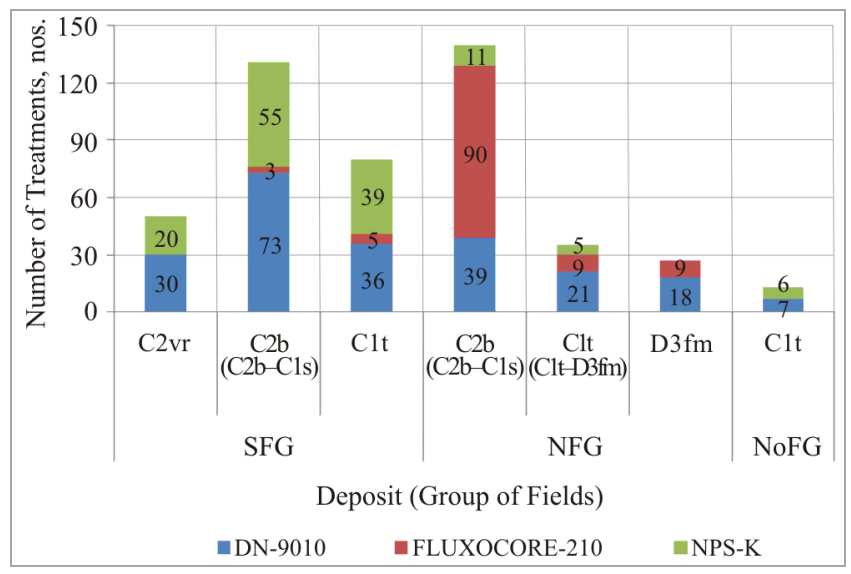

Fig. 4. Distribution of treatments with different acid compositions at carbonate deposits of the Perm Region
DN-9010 acid composition was used at the fields of the Perm Region from 2003 to 2016, with a total of 224 acid treatments performed. FLUXOCORE-210 and NPS-K compositions were brought into use in 2011 and 2014, respectively, and are being actively used, including 136 acid treatments with NPS-K and 116 with FLUXOCORE -210, overall.

The application of acid formulations was distributed across carbonate deposits of the SFG, NFG and NoFG as given in Fig. 4. A considerable part of acid treatment jobs at productive formations with DN-9010, FLUXOCORE-210 and NPS-K fell

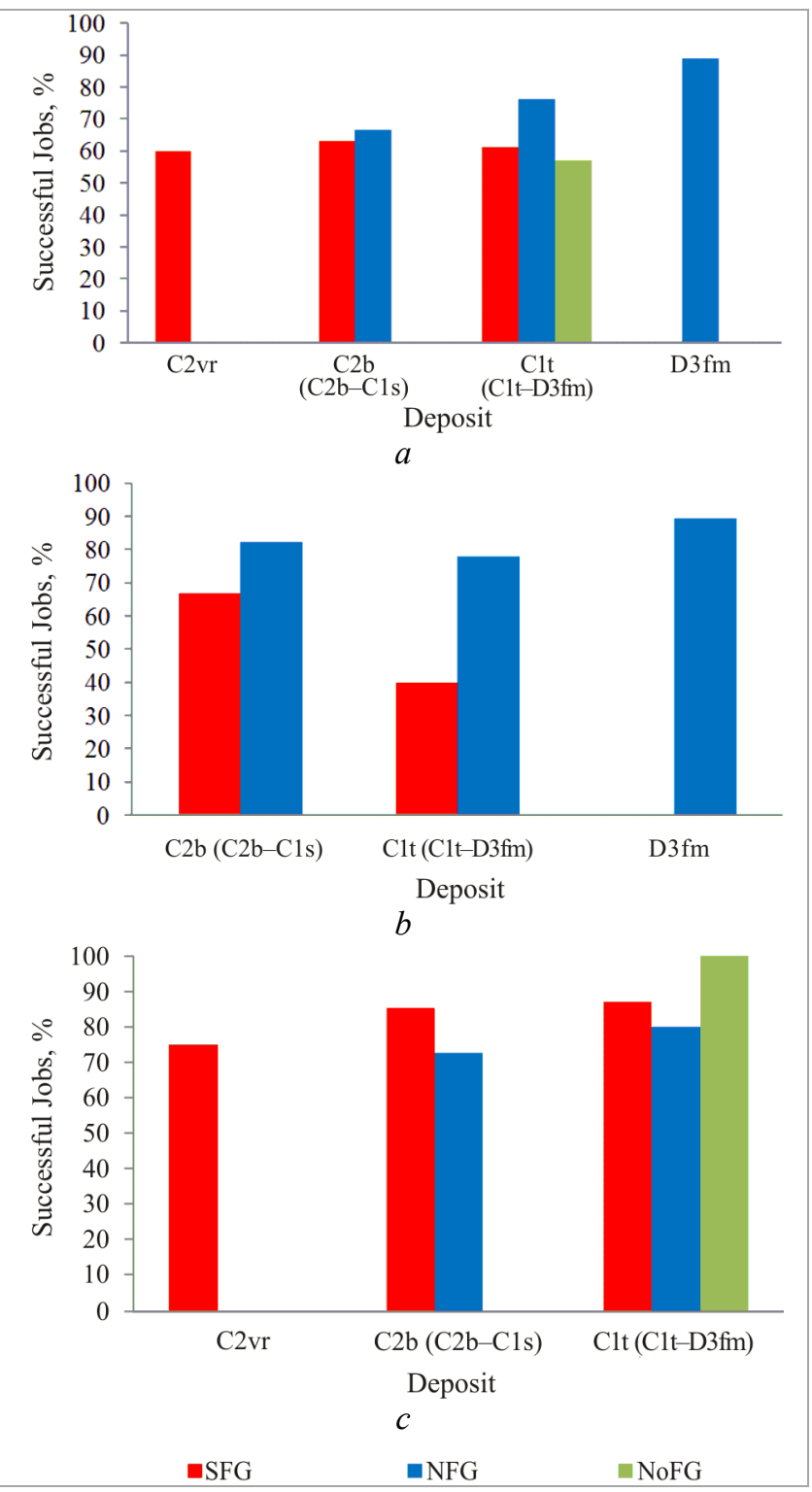

Fig. 5. Successful acid treatments at carbonate deposits of The Perm Region: $a-\mathrm{DN}-9010$; $b$-FLUXOCORE-210; $c$ - NPS-K 
upon the deposits of the SFG (55\%) and the NFG (42\%), mainly Bashkirian (BashkirianSerpukhovian) and Tournaisian (TournaisianFamennian) deposits. Tournaisian deposits of the NoFG accounted for 13 acid treatments only, of which six with NPS-K and seven with DN-9010.

Fig. 5 provides a diagram illustrating the proportion of successful acid treatments, i.e. the treatments that have reached the target oil production growth, with the compositions under study. The least successful was the acid treatment at the Tournaisian deposits of the NoFG with the DN-9010 composition, which accounted for $57 \%$ jobs only. Application of the NPS-K composition under the same conditions delivered the target growth for all the jobs performed (100\%). Furthermore, positive practice of acid treatments with FLUXOCORE-210 at the NFG deposits shall be noted, with $78-90 \%$ of jobs successful.
The number of successful jobs with NPS-K and FLUXOCORE-210 compositions is generally higher than those with DN-9010 (up to 1.75 times), which suggests their better correspondence to geological and physical features of complex carbonate deposits in the Perm Region.

\section{Efficiency of Treatment with DN-9010, FLUXOCORE-210 and NPS-K Acid Compositions}

To characterize the results of oil production stimulation measures, the so-called process efficiency indicators are most commonly used, including oil production growth rate, additional oil production and duration of the effect [41-43]. However, for the theory and practice of oil field development, the study of the efficiency of measures based on changes in well productivity and flow properties of the formation $[44,45]$ is of great interest.

Table 3

Change in Well Productivity Index after Acid Treatment

\begin{tabular}{|c|c|c|c|c|c|c|}
\hline \multirow[b]{2}{*}{ Deposit } & \multicolumn{2}{|c|}{ SFG } & \multicolumn{2}{|c|}{ NFG } & \multicolumn{2}{|c|}{ NoFG } \\
\hline & $\begin{array}{c}\text { Number of } \\
\text { Treatments, nos. }\end{array}$ & $\begin{array}{c}K_{\mathrm{p} 2} / K_{\mathrm{p} 1} \\
\text { unit fractions }\end{array}$ & $\begin{array}{c}\text { Number of } \\
\text { Treatments, nos. }\end{array}$ & $\begin{array}{c}K_{\mathrm{p} 2} / K_{\mathrm{p} 1} \\
\text { unit fractions. }\end{array}$ & $\begin{array}{c}\text { Number of } \\
\text { Treatments, nos. }\end{array}$ & $\begin{array}{c}K_{\mathrm{p} 2} / K_{\mathrm{p} 1} \\
\text { unit fractions }\end{array}$ \\
\hline \multicolumn{7}{|c|}{ DN-9010 } \\
\hline $\mathrm{C}_{2} \mathrm{vr}$ & 4 & $\frac{1,03-2,60}{1,71}$ & - & - & - & - \\
\hline $\begin{array}{l}\mathrm{C}_{2} \mathrm{~b} \\
\left(\mathrm{C}_{2} \mathrm{~b}-\mathrm{C}_{1} \mathrm{~s}\right)\end{array}$ & 15 & $\frac{0,08-5,17}{2,20}$ & 13 & $\frac{0,59-5,64}{2,47}$ & - & - \\
\hline $\begin{array}{l}\mathrm{C}_{1} \mathrm{t} \\
\left(\mathrm{C}_{1} \mathrm{t}-\mathrm{D}_{3} \mathrm{fm}\right)\end{array}$ & 7 & $\frac{0,60-4,19}{1,83}$ & 10 & $\frac{0,37-8,91}{2,14}$ & 3 & $\frac{0,49-2,97}{1,65}$ \\
\hline $\mathrm{D}_{3} \mathrm{fm}$ & - & - & 13 & $\frac{0,09-13,90}{3,00}$ & - & - \\
\hline \multicolumn{7}{|c|}{ FLUXOCORE - 210} \\
\hline $\begin{array}{l}\mathrm{C}_{2} \mathrm{~b} \\
\left(\mathrm{C}_{2} \mathrm{~b}-\mathrm{C}_{1} \mathrm{~s}\right)\end{array}$ & - & - & 64 & $\frac{0,37-23,31}{2,35}$ & - & - \\
\hline $\begin{array}{l}\mathrm{C}_{1} \mathrm{t} \\
\left(\mathrm{C}_{1} \mathrm{t}-\mathrm{D}_{3} \mathrm{fm}\right)\end{array}$ & 3 & $\frac{0,43-1,32}{0,76}$ & 6 & $\frac{0,49-10,80}{3,33}$ & - & - \\
\hline $\mathrm{D}_{3} \mathrm{fm}$ & - & - & 5 & $\frac{0,34-13,03}{3,32}$ & - & - \\
\hline \multicolumn{7}{|c|}{ NPS-K } \\
\hline $\mathrm{C}_{2} \mathrm{vr}$ & 7 & $\frac{1,00-13,40}{5,22}$ & - & - & - & - \\
\hline $\begin{array}{l}\mathrm{C}_{2} \mathrm{~b} \\
\left(\mathrm{C}_{2} \mathrm{~b}-\mathrm{C}_{1} \mathrm{~s}\right.\end{array}$ & 7 & $\frac{0,57-7,84}{2,42}$ & 3 & $\frac{0,82-4,38}{2,88}$ & - & - \\
\hline $\begin{array}{l}\mathrm{C}_{1} \mathrm{t} \\
\left(\mathrm{C}_{1} \mathrm{t}-\mathrm{D}_{3} \mathrm{fm}\right)\end{array}$ & 15 & $\frac{0,44-7,05}{2,03}$ & - & - & 3 & $\frac{5,12-30,55}{15,52}$ \\
\hline
\end{tabular}

Note : $K_{\mathrm{p} 2}, K_{\mathrm{p} 1}$ are well productivity indices after and before acid treatment; $K_{\mathrm{p} 2} / K_{\mathrm{p} 1}$ is change of well productivity index as a result of acid treatment (numerator is a range of indicator values; denominator is a mean value). 
In connection with the foregoing, the results of acid treatments carried out on wells running on carbonate deposits of the Perm Region were evaluated based on the interpretation of hydrodynamic research materials. For this purpose, all pressure (level) build-up curves obtained on productive wells shortly before and after the acid treatment were used: total of 356 tests, or 178 pairs, which, as it should be stated, covers only $22.2 \%$ of the jobs performed with the compositions under study at the SFG, $56.4 \%$ at the NFG, and $46.2 \%$ at the NoFG. The hydrodynamic research data were interpreted using KAPPA Workstation software product (Saphir NL module), deterministic moments of pressure, and the integral method of Barenblatt, Borisov, Kamenetsky, and Krylov [46]. As it was established, the results of acid treatments differ quite strongly depending on the applied composition (Tables 3-5).

To determine the change in well productivity after exposure (see Table 3), the values of formation pressure before and after the treatment were calculated by the product method [47]. The maximum increase in the productivity index after acid treatments with DN-9010 composition was established at the NFG Famennian deposit (by 3 times, on average, based on 13 pairs of tests), FLUXOCORE-210 - at the NFG Tournaisian and Tournaisian-Famennian deposits (3.3 times), NPS$\mathrm{K}$ - at the NoFG Tournaisian deposit (15.5 times). Decrease in well productivity was observed at the SFG Tournaisian deposits after application of FLUXOCORE-210 composition (by 1.3 times), which might be caused by a number of factors to be discussed further.

Table 4

Change in BHZ Permeability Index after Acid Treatment

\begin{tabular}{|c|c|c|c|c|c|c|}
\hline \multirow[b]{2}{*}{ Deposit } & \multicolumn{2}{|c|}{ SFG } & \multicolumn{2}{|c|}{ NFG } & \multicolumn{2}{|c|}{ NoFG } \\
\hline & $\begin{array}{c}\text { Number of } \\
\text { Treatments, nos. }\end{array}$ & $\begin{array}{l}\mathrm{K}_{\mathrm{BHZ} 2} / \mathrm{K}_{\mathrm{BHZ} 1} \\
\text { unit fractions }\end{array}$ & $\begin{array}{c}\text { Number of } \\
\text { Treatments, nos. }\end{array}$ & $\begin{array}{l}\mathrm{K}_{\mathrm{BHZ} 2} / \mathrm{K}_{\mathrm{BHZ1}} \\
\text { unit fractions }\end{array}$ & $\begin{array}{c}\text { Number of } \\
\text { Treatments, nos. }\end{array}$ & $\begin{array}{c}\mathrm{K}_{\mathrm{BHZ} 2} / \mathrm{K}_{\mathrm{BHZ1}} \\
\text { unit fractions }\end{array}$ \\
\hline \multicolumn{7}{|c|}{ DN-9010 } \\
\hline $\mathrm{C}_{2} \mathrm{vr}$ & 4 & $\frac{0,69-2,56}{1,83}$ & - & - & - & - \\
\hline $\begin{array}{l}\mathrm{C}_{2} \mathrm{~b} \\
\left(\mathrm{C}_{2} \mathrm{~b}-\mathrm{C}_{1} \mathrm{~s}\right)\end{array}$ & 15 & $\frac{0,06-5,61}{2,28}$ & 13 & $\frac{0,60-5,16}{2,62}$ & - & - \\
\hline $\begin{array}{l}\mathrm{C}_{1} \mathrm{t} \\
\left(\mathrm{C}_{1} \mathrm{t}-\mathrm{D}_{3} \mathrm{fm}\right)\end{array}$ & 7 & $\frac{0,75-10,66}{3,00}$ & 10 & $\frac{0,37-8,99}{2,95}$ & 3 & $\frac{2,50-8,35}{5,43}$ \\
\hline $\mathrm{D}_{3} \mathrm{fm}$ & - & - & 13 & $\frac{0,09-14,33}{3,34}$ & - & - \\
\hline \multicolumn{7}{|c|}{ FLUXOCORE - 210} \\
\hline $\begin{array}{l}\mathrm{C}_{2} \mathrm{~b} \\
\left(\mathrm{C}_{2} \mathrm{~b}-\mathrm{C}_{1} \mathrm{~s}\right)\end{array}$ & - & - & 64 & $\frac{0,16-27,02}{3,19}$ & - & - \\
\hline $\begin{array}{l}\mathrm{C}_{1} \mathrm{t} \\
\left(\mathrm{C}_{1} \mathrm{t}-\mathrm{D}_{3} \mathrm{fm}\right)\end{array}$ & 3 & $\frac{0,28-0,52}{0,37}$ & 6 & $\frac{0,16-53,75}{11,02}$ & - & - \\
\hline $\mathrm{D}_{3} \mathrm{fm}$ & - & - & 5 & $\frac{0,19-10,15}{2,52}$ & - & - \\
\hline \multicolumn{7}{|c|}{ NPS-K } \\
\hline $\mathrm{C}_{2} \mathrm{vr}$ & 7 & $\frac{0,84-13,26}{5,81}$ & - & - & - & - \\
\hline $\begin{array}{l}\mathrm{C}_{2} \mathrm{~b} \\
\left(\mathrm{C}_{2} \mathrm{~b}-\mathrm{C}_{1} \mathrm{~s}\right)\end{array}$ & 7 & $\frac{0,23-13,75}{3,44}$ & 3 & $\frac{0,98-14,6}{7,90}$ & - & - \\
\hline $\begin{array}{l}\mathrm{C}_{1} \mathrm{t} \\
\left(\mathrm{C}_{1} \mathrm{t}-\mathrm{D}_{3} \mathrm{fm}\right)\end{array}$ & 15 & $\frac{0,39-8,57}{2,06}$ & - & - & 3 & $\frac{3,58-20,59}{10,40}$ \\
\hline
\end{tabular}

N o te : $K_{\mathrm{BHZ} 2}, K_{\mathrm{BHZ} 1}$ are BHZ permeability indices after and before acid treatment; $K_{\mathrm{BHZ} 2} / K_{\mathrm{BHZ} 1}$ is change of the BHZ permeability index as a result of acid treatment (numerator is a range of indicator values; denominator is a mean value). 
According to the comparative analysis of hydrodynamic studies, in addition to the change in the permeability of the bottomhole zone (Table 4), the fact of change in the permeability of the farfield zone was established (Table 5). There are several possible reasons for this phenomenon: the acid composition both dissolves calcite in the healed fractures, which results in bringing into development of the earlier undrained areas of the deposit by the area and/or the section, and penetrates deeply, as well.

Within the scope of this research, it is only possible to state that the permeability of the farfield zone (FFZ) has changed, without identifying the specific factors that caused it.

After acid treatments at carbonate deposits of the SFM and NoFG, the largest increase in the
BHZ permeability was observed after the application of NPS-K composition: 2.1-5.8 and 10.4 times, respectively. FLUXOCORE-210 acid composition is more effective for the NFG; its application increased the BHZ permeability by 2.5-11.0 times. The application of this composition at the Tournaisian deposits of the SFG resulted in decrease in the BHZ permeability by 2.7 times on average, based on 3 pairs of tests.

The NPS-K composition is mostly effective at increasing the permeability of FFZ in the conditions of the carbonate deposits of the SFG and NoFG: by 1.6-5.7 and 9.3 times, respectively, while FLUXOCORE-210 proved effective at the NFG, except for the Famennian deposits with a decrease in the FFZ permeability by 1.2 times, based on 5 pairs of tests.

Table 5

Change in FFZ Permeability Index after Acid Treatment

\begin{tabular}{|c|c|c|c|c|c|c|}
\hline \multirow[b]{2}{*}{ Deposit } & \multicolumn{2}{|c|}{ SFG } & \multicolumn{2}{|c|}{ NFG } & \multicolumn{2}{|c|}{ NoFG } \\
\hline & $\begin{array}{c}\text { Number of } \\
\text { Treatments, nos. }\end{array}$ & $\begin{array}{c}K_{\mathrm{FFZ2} 2} / K_{\mathrm{FFZ1}} \\
\text { unit fractions }\end{array}$ & $\begin{array}{c}\text { Number of } \\
\text { Treatments, nos. }\end{array}$ & $\begin{array}{l}K_{\mathrm{FFZ2}} / K_{\mathrm{FFZ1}} \\
\text { unit fractions }\end{array}$ & $\begin{array}{c}\text { Number of } \\
\text { Treatments, nos. }\end{array}$ & $\begin{array}{c}K_{\mathrm{FFZ} 2} / K_{\mathrm{FFZ1}} \\
\text { unit fractions }\end{array}$ \\
\hline \multicolumn{7}{|c|}{ DN-9010 } \\
\hline $\mathrm{C}_{2} \mathrm{vr}$ & 4 & $\frac{0,99-3,11}{2,09}$ & - & - & - & - \\
\hline $\begin{array}{l}\mathrm{C}_{2} \mathrm{~b} \\
\left(\mathrm{C}_{2} \mathrm{~b}-\mathrm{C}_{1} \mathrm{~s}\right)\end{array}$ & 15 & $\frac{0,02-14,57}{3,05}$ & 13 & $\frac{0,55-3,80}{1,56}$ & - & - \\
\hline $\begin{array}{l}\mathrm{C}_{1} \mathrm{t} \\
\left(\mathrm{C}_{1} \mathrm{t}-\mathrm{D}_{3} \mathrm{fm}\right)\end{array}$ & 7 & $\frac{0,19-3,36}{1,22}$ & 10 & $\frac{0,52-9,50}{3,12}$ & 3 & $\frac{0,41-5,03}{2,73}$ \\
\hline $\mathrm{D}_{3} \mathrm{fm}$ & - & - & 13 & $\frac{0,10-20,50}{4,92}$ & - & - \\
\hline \multicolumn{7}{|c|}{ FLUXOCORE-210 } \\
\hline $\begin{array}{l}\mathrm{C}_{2} \mathrm{~b} \\
\left(\mathrm{C}_{2} \mathrm{~b}-\mathrm{C}_{1} \mathrm{~s}\right)\end{array}$ & - & - & 64 & $\frac{0,12-28,7}{3,07}$ & - & - \\
\hline $\begin{array}{l}\mathrm{C}_{1} \mathrm{t} \\
\left(\mathrm{C}_{1} \mathrm{t}-\mathrm{D}_{3} \mathrm{fm}\right)\end{array}$ & 3 & $\frac{0,25-0,93}{0,57}$ & 6 & $\frac{0,05-51,7}{10,68}$ & - & - \\
\hline $\mathrm{D}_{3} \mathrm{fm}$ & - & - & 5 & $\frac{0,15-2,15}{0,86}$ & - & - \\
\hline \multicolumn{7}{|c|}{ NPS-K } \\
\hline $\mathrm{C}_{2} \mathrm{vr}$ & 7 & $\frac{0,32-23,83}{5,67}$ & - & - & - & - \\
\hline $\begin{array}{l}\mathrm{C}_{2} \mathrm{~b} \\
\left(\mathrm{C}_{2} \mathrm{~b}-\mathrm{C}_{1} \mathrm{~s}\right)\end{array}$ & 7 & $\frac{0,24-3,25}{1,62}$ & 3 & $\frac{0,44-2,61}{1,45}$ & - & - \\
\hline $\begin{array}{l}\mathrm{C}_{1} \mathrm{t} \\
\left(\mathrm{C}_{1} \mathrm{t}-\mathrm{D}_{3} \mathrm{fm}\right)\end{array}$ & 15 & $\frac{0,11-7,58}{1,99}$ & - & - & 3 & $\frac{3,07-23,99}{9,31}$ \\
\hline
\end{tabular}

$\mathrm{N}$ o te : $K_{\mathrm{FFZ} 2}, K_{\mathrm{FFZ} 1}$ are FFZ permeability indices after and before acid treatment; $K_{\mathrm{FFZ}} / K_{\mathrm{FFZ} 1}$ is change of FFZ permeability index as a result of acid treatment (numerator is a range of indicator values; denominator is a mean value). 
As previously stated, after acid treatments of carbonate deposits of the SFG using FLUXOCORE-210 composition, there was a decrease in flow properties of both bottomhole and farfield zones and, as a result, of well productivity. This can be the result of the killing fluid flow into reservoir, the reservoir damage with products of acid and rock reaction, or the incompatibility of the acid composition with formation fluids, which entails pore plugging with high-viscosity oil emulsions or solid precipitation from formation water. To identify specific factors that resulted in the decrease in flow properties, a set of studies shall be conducted, including testing of both void space and core sample flow with simulation of thermodynamic conditions of productive formations and saturation of samples with real reservoir fluids.

According to the analysis of changes in well productivity and permeability of BHZ and FFZ after acid treatment with the compositions under study, it is possible to identify a slightly higher efficiency of NPS-K and FLUXOCORE-210 compositions in comparison with DN-9010. NPS$\mathrm{K}$ acid composition shows better results at carbonate deposits of the SFG and NoFG, while FLUXOCORE-210 - at the NFG.

Further to the acid compositions under study, NPS-K1, a new high-potential acid composition by OOO NefteProm Service (Perm), is worth noting, as it allows treatments without involvement of a well workover crew due to a significantly reduced corrosion rate, thus reducing the job cost. The NPS-K1 composition is a reverse hydrocarbon emulsion, in which liquid hydrocarbons are the dispersion medium and hydrochloric acid is the dispersion phase. When in contact with reservoir oil, the emulsion breaks down into the hydrocarbon and acid phases, in which case the hydrocarbon phase clears the bottomhole zone of paraffin deposits, while the acid phase reacts directly with the rock, thus increasing the reservoir permeability. A low number of treatment jobs with NPS-K1 acid composition at carbonate deposits of the Perm Region (only 10 jobs in Vereiskian, Bashkirian and Tournaisian deposits of SFG and NoFG performed since the end of 2017) does not currently allow a detailed analysis of its efficiency.

\section{Conclusions}

1. Carbonate deposits of the Perm Region are characterized by a complex geology, diverse structure of the void space and composition of the rocks.

2. Acid treatments in carbonate reservoirs are complicated by their low permeability, significant content of insoluble minerals (Southern group of fields), increased dolomitization and natural fracturing, and vuggy porosity (Northern group of fields) of reservoir rocks, as well as high viscosity of reservoir oil (Nozhovskaya group of fields).

3. The number of acid treatments that have reached the target oil production growth with FLUXOCORE-210 and NPS-K compositions exceeds the number of successful treatments with DN-9010 composition.

4. According to the analysis of changes in well productivity and permeability of bottomhole and farfield zones after acid treatments, it is also possible to determine a slightly higher efficiency of NPS-K and FLUXOCORE-210 compositions in comparison with DN-9010. NPS-K acid composition shows better results at carbonate deposits of the Southern and Nozhovskaya groups of fields, while FLUXOCORE -210 - at the Northern group of fields.

5. With sufficient practice in the application of NPS-K1 acid composition in the fields of the Perm Region, its effectiveness shall be analysed similarly to DN-9010, FLUXOCORE-210 and NPS-K compositions discussed in this paper.

\section{References}

1. Ramazanov R.R., Kharlamov K.A., Letko I.I., Martseniuk R.A. Analiz effektivnosti geologotekhnicheskikh meropriiatii [Efficiency analysis of geological and technical measures].
Oil Industry, 2019, no. 6, pp.62-65. DOI: 10.24887/0028-2448-2019-6-62-65

2. Iktisanov V.A., Sakhabutdinov R.Z. Otsenka tekhnologicheskoi effektivnosti 
metodov intensifikatsii dobychi nefti i uvelicheniia nefteotdachi pri pomoshchi analiza dinamiki dobychi [Evaluation of effectiveness of EOR and bottomhole treatment technologies using rate transient analysis]. Oil industry, 2019, no.5, pp.72-76. DOI: 10.24887/0028-2448-2019-5-72-76

3. Borkhovich S.Iu., Pchel'nikov I.V., Natarov A.L. Formirovanie kriteriev podbora skvazhin dlia provedeniia geologo-tekhnicheskikh meropriiatii [Developing criteria of wells selection for geological and engineering operations]. Oil industry, 2018, no.4, pp.80-83. DOI: $10.24887 / 0028-2448-2018-4-80-83$

4. Raspopov A.V., Novokreshchennykh D.V. Analiz rezul'tatov primeneniya metodov intensifikacii na karbonatnyh kollektorah mestorozhdenij Permskogo kraya [Results analysis of intensification methods application in carbonate reservoirs of Perm region fields]. Perm Journal of Petroleum and Mining Engineering, 2014, no.10. pp.73-82. DOI: $10.15593 / 2224-9923 / 2014.10 .7$

5. Zeigman Iu.V., Sergeev V.V., Ayupov R.R. Klassifikatsiia fiziko-khimicheskikh metodov intensifikatsii dobychi nefti po mekhanizmu vozdeistviia na plastovuiu sistemu [Classification of physico-chemical methods applied to stimulate oil production according with their effect on a formation system]. Geology, geophysics and development of oil and gas fields, 2017, no.1, pp.50-53.

6. Novokreshchennykh D.V., Raspopov A.V. Effektivnost' realizatsii tekhnologii radial'nogo bureniia i matrichnykh kislotnykh obrabotok karbonatnykh kollektorov mestorozhdenii Permskogo kraia [Efficiency of radial drilling and acidizing technologies in carbonate reservoirs of Perm Region]. Oil industry, 2016, no.4, pp.118-121.

7. Mordvinov V.A. Mekhanizm vozdeistviia solianokislotnykh rastvorov na karbonatnyi kollektor [The influence mechanism of hydrochlorid-acid solutions on a carbonate collector]. Oil industry, 2011, no.1, pp.44-46.

8. Khizhnyak G.P., Ponomareva I.N., Amirov A.M., Glushchenko V.N. Opredelenie optimal'noi skorosti zakachki kislotnykh sostavov po rezul'tatam issledovanii na kernakh [Determination of the optimal rate of injection acid compositions on the results of research on the core samples]. Oil industry, 2014, no.6, pp.52-54.

9. Zakirov T.R., Nikiforov A.I. Modelirovanie kislotnogo vozdeistviia na neftianye plasty pri zavodnenii [Modeling acid impact in water flooding oil reservoir]. Oil industry, 2012, no.6, pp.62-65.

10. Liu P., Yao J., Couples G.D., Ma J. et. al. Modeling and simulation of wormhole formation during acidization of fractured carbonate rocks. Journal of Petroleum Science and Engineering, 2017, vol.154, pp.284-301. DOI: 10.1016/j.petrol.2017.04.040

11. Qiu X., Aidagulov G., Ghommem M., Edelman E. et. al. Towards a better understanding of wormhole propagation in carbonate rocks: linear vs. radial acid injection. Journal of Petroleum Science and Engineering, 2018, vol.171, pp.570-583. DOI: $10.1016 /$ j.petrol.2018.07.075

12. Zeigman Iu.V., Lysenkov A.V., Mukhametshin V.V., Sultanov Sh.Kh. et. al. $\mathrm{K}$ voprosu vybora tekhnologii kislotnogo vozdeistviia dlia intensifikatsii dobychi nefti [Some aspects of an acidizing technology choice to enhance oil production]. Geology, geophysics and development of oil and gas fields, 2017, no. 6, pp. 44-50.

13. Vakhrushev S.A., Folomeev A.E., Kotenev Iu.A., Nabiullin R.M. Issledovanie kislotnogo vozdeistviia $\mathrm{s}$ primeneniem potokootklonitelei na karbonatnye kollektory mestorozhdeniia imeni R. Trebsa [Acid treatment with diverting on carbonate reservoirs of R. Trebs oil field]. Oil industry, 2016, no.4, pp.112-117.

14. Nasibulin I.M., Kornil'tsev L.A., Vasiasin G.I., Baimashev B.A. Sistemnyi podkhod k kislotnym obrabotkam prizaboinykh zon skvazhin [System approach to acid treatment of wellbore zones]. Oilfield engineering. 2009, no.2, pp.21-26.

15. Shirazi M.M., Ayatollahi S., Ghotbi C. Damage evaluation of acid-oil emulsion and asphaltic sludge formation caused 
by acidizing of asphaltenic oil reservoir. Journal of Petroleum Science and Engineering, 2019, vol.174, pp.880-890. DOI: $10.1016 /$ j.petrol.2018.11.051

16. Assem A.I., Kumar H.T., Nasr-El-Din H.A., De Wolf C.A. Location and magnitude of formation damage due to iron precipitation during acidizing carbonate rocks. Journal of Petroleum Science and Engineering, 2019, vol.179, pp. 337-354. DOI: $10.1016 /$ j.petrol.2019.04.073

17. Ituen E., Mkpenie V., Dan E. Surface protection of steel in oil well acidizing fluids using L-theanine-based corrosion inhibitor formulations: experimental and theoretical evaluation. Surfaces and Interfaces, 2019, vol.16, pp.29-42. DOI: $10.1016 /$ j.surfin.2019.04.006

18. Finšgar M., Jackson J. Application of corrosion inhibitors for steels in acidic media for the oil and gas industry: a review. Corrosion Science, 2014, vol.86, pp.17-41. DOI: 10.1016/j.corsci.2014.04.044

19. Glushchenko V.N. Funktsional'naia rol' PAV $\mathrm{v}$ kislotnykh sostavakh [The functional role of surfactants in acid compositions]. Geology, geophysics and development of oil and gas fields, 2008, no.2, pp.27-35.

20. Carvalho R.T.R., Oliveira P.F., Palermo L.C.M., Ferreira A.A.G. et. al. Prospective acid microemulsions development for matrix acidizing petroleum reservoirs. Fuel, 2019, vol.238, pp.75-85. DOI: 10.1016/j.fuel.2018.10.003

21. Folomeev A.E., Vakhrushev S.A., Sharifullin A.R., Lenchenkova L.E. et. al. Kompleksnyi podkhod $\mathrm{k}$ razrabotke dizaina kislotnykh obrabotok skvazhin mestorozhdeniia im. R. Trebsa [Integrated approach to well acidizing design on R. Trebs oil field (Timan-Pechora Basin)]. Oil industry, 2014, no.8, pp.72-75.

22. Kharisov R.Ia., Folomeev A.E., Bulgakova G.T., Telin A.G. Kompleksnyi podkhod $\mathrm{k}$ vyboru optimal'nogo kislotnogo sostava dlia stimuliatsii skvazhin $\mathrm{v}$ karbonatnykh kollektorakh [The complex approach to the choice of the optimum acid composition for well stimulation in carbonate]. Oil industry, 2011, no.2, pp.78-82.

23. Folomeev A.E., Vakhrushev A.S., Mikhailov A.G. Ob optimizatsii kislotnykh sostavov dlia primeneniia $\mathrm{v}$ geologotekhnologicheskikh usloviiakh mestorozhdenii OAO ANK "Bashneft" [On the optimization of acid compositions for geotechnical conditions of oilfields of Bashneft JSOC]. Oil industry, 2013, no.11, pp.108-112.

24. Khakimov A.A., Sattarov R.I., Kachurin A.V., Akimkin A.V. Sovershenstvovanie tekhnologii kislotnykh obrabotok [Acid treatment technological advancement]. Oil industry, 2012, no.3, pp.54-55.

25. Garrouch A.A., Jennings A.R. A contemporary approach to carbonate matrix acidizing. Journal of Petroleum Science and Engineering, 2017, vol.158, pp.129-143. DOI: $10.1016 /$ j.petrol.2017.08.045

26. Nasibulin I.M., Misolina N.A., Baimashev N.A. Sovremennye predstavleniia o vliianii geologicheskikh faktorov, opredeliaiushchikh protsess vzaimodeistviia kislotnykh rastvorov s karbonatnoi porodoi [Modern ideas about the influence of geological factors that determine the process of interaction of acidic solutions with carbonate rock]. Geology, geophysics and development of oil and gas fields, 2011, no.3, pp.56-61.

27. Odintsova Iu.V. Vliianie fil'tratsionnoemkostnykh svoistv i plastovykh uslovii na effektivnost' kislotnykh obrabotok karbonatnogo plasta [Influence of reservoir properties and reservoir conditions on the efficiency of acid treatments of the carbonate reservoir]. GAS Industry of Russia, 2012, no.6, pp.38-40.

28. Ibragimov N.G., Zabbarov R.G., Daminov A.M., Kozikhin R.A. Analiz faktorov, vliiaiushchikh na effektivnost' solianokislotnykh obrabotok [Analysis of factors influencing the efficiency of hydrochloric acid treatments]. Oil Industry, 2014, no.1, pp.70-71.

29. Karimi M., Shirazi M.M., Ayatollahi S. Investigating the effects of rock and fluid properties in Iranian carbonate matrix acidizing during pre-flush stage. Journal of Petroleum 
Science and Engineering, 2018, vol.166, pp.121-130. DOI: 10.1016/j.petrol.2018.03.002

30. Ma G., Chen Y., Jin Y., Wang H. Modelling temperature-influenced acidizing process in fractured carbonate rocks. International Journal of Rock Mechanics and Mining Sciences, 2018, vol.105, pp.73-84. DOI: 10.1016/j.ijrmms.2018.03.019

31. Martyushev D.A. Laboratornye issledovaniia kislotnykh sostavov dlia obrabotki kollektorov, kharakterizuiushchikhsia razlichnoi karbonatnost'iu i strukturoi pustotnogo prostranstva gornykh porod [Laboratory studies of acid compositions for treating reservoir, characterized by various carbonate content and void structure of rocks]. Bulletin of the Tomsk Polytechnic University. Geo Assets Engineering, 2018, vol.329, iss.4, pp.6-12.

32. Sungatullin R.Kh., Islamova R.R., Kadyrov R.I., Sungatullina G.M. Traditsionnye i pretsizionnye metody izucheniia porovogo prostranstva neftenosnykh kollektorov [Traditional and precision methods for studying porous space of oil-bearing formation]. Oil industry, 2017, no.11, pp.89-91. DOI: 10.24887/0028-2448-2017-11-89-91

33. Iazynina I.V., Sheliago E.V., Abrosimov A.A., Grachev N.E. et. al. Opredelenie ostatochnoi vodonasyshchennosti porod-kollektorov metodom rentgenovskoi tomografii [Determination of reservoir rock residual water using X-ray computed microtomography]. Oil Industry, 2018, no.3, pp.38-42. DOI: 10.24887/0028-2448-2018-3-38-42

34. Machado A.C., Oliveira T.J.L., Cruz F.B., Lopes R.T. et. al. X-ray microtomograph of hydrochloric acid propagation in carbonate rocks. Applied Radiation and Isotopes, 2015, vol.96, pp.129-134. DOI: $10.1016 /$ j.apradiso.2014.10.027

35. Safari A., Dowlatabad M.M., Hassani A., Rashidi F. Numerical simulation and X-ray imaging validation of wormhole propagation during acid core-flood experiments in a carbonate gas reservoir. Journal of Natural Gas Science and Engineering, 2016, vol.30, pp.539-547. DOI: $10.1016 /$ j.jngse.2016.02.036
36. Ghommem M., Zhao W., Dyer S., Qiu X. et. al. Carbonate aciding: modeling, analysis, and characterization of wormhole formation and propagation. Journal of Petroleum Science and Engineering, 2015, vol.131, pp.18-33. DOI: 10.1016/j.petrol.2015.04.021

37. Machado A.C., Teles A.P., Pepin A., Bize-Forest N. et. al. Porous media investigation before and after hydrochloric acid injection on a pre-salt carbonate coquinas sample. Applied Radiation and Isotopes, 2016, vol.110, pp.160-163. DOI: $10.1016 /$ j.apradiso.2016.01.005

38. Dong K., Zhu D., Hill A.D. The role of temperature on optimal conditions in dolomite acidizing: an experimental study and its applications. Journal of Petroleum Science and Engineering, 2018, vol.165, pp.736-742. DOI: 10.1016/j.petrol.2018.03.018

39. Yoo H., Kim Y., Lee W., Lee J. An experimental study on acid-rock reaction kinetics using dolomite in carbonate acidizing. Journal of Petroleum Science and Engineering, 2018, vol.168, pp.478-494. DOI: 10.1016/j.petrol.2018.05.041

40. Zhang K., Zhu X.K., Yan B. A refined dissolution method for rare earth element studies of bulk carbonate rock. Chemical Geology, 2015, vol.412, pp.82-91. DOI: 10.1016/j.chemgeo.2015.07.027

41. Zakharian A.G., Musin R.M., Cimic M. Analiz effektivnosti fiziko khimicheskikh metodov uvelicheniia nefteotdachi plastov na obktakh OAO "NK Rosneft" [Analyzing the efficiency of chemical EOR methods for oil fields developing by Rosneft Oil Company]. Oil industry, 2015, no.8, pp.58-59.

42. Ibragimov N.G., Musabirov M.Kh., Iartiev A.F. Opyt promyshlennoi realizatsii importzameshchaiushchikh tekhnologii intensifikatsii dobychi nefti v PAO "Tatneft" [Tatnefts experience in commercialization of import-substituting well stimulation technologies]. Oil industry, 2015, no.8, pp.86-89.

43. Firsov V.V., Kuznetsov M.A., Popov A.Iu., Sagitov D.K. Vyiavlenie kriteriev uspeshnogo primeneniia soliano-kislotnykh obrabotok po plastam okskogo nadgorizonta Sorochinsko- 
Nikol'skogo mestorozhdeniia [Revealing criteria of successful application of hydrochloric acid treatment of the oksky up-horizon layers of Sorochinsko-Nikolsky field]. Geology, geophysics and development of oil and gas fields, 2011, no.2, pp.70-76.

44. Martyushev D.A., Ponomareva I.N. Issledovanie osobennostei vyrabotki zapasov treshchinno-porovykh kollektorov s ispolzovaniem dannykh gidrodinamicheskikh issledovanii skvazhin [Researching features of development of fractured porous reservoirs reserves using well-test data]. Oil industry, 2017, no.10, pp.102-104. DOI: 10.24887/0028-2448-2017-10-102-104

45. Cherepanov S.S., Martyushev D.A., Ponomareva I.N. Otsenka fil'tratsionno-emkostnykh svoistv treshchinovatykh karbonatnykh kollektorov mestorozhdenii Preduralskogo kraevogo progiba [Evaluation of filtrationcapacitive properties of fractured carbonate reservoir of Predural'skogo edge deflection]. Oil industry, 2013, no.3, pp.62-65.

46. Ponomareva I.N. K obrabotke krivykh vosstanovleniia davleniia nizkoproduktivnykh skvazhin [For processing of recovery curves of pressure of low-productive wells]. Oil industry, 2010, no.6, pp.78-79.

47. Erofeev A.A., Ponomareva I.N., Mordvinov V.A. K opredeleniiu plastovogo davleniia pri gidrodinamicheskikh issledovaniiakh skvazhin $\mathrm{V}$ karbonatnykh kollektorakh [To definition of reservoir pressure at hydrodynamic researches of wells of the carbonate collector]. Oil industry, 2013, no.4, pp.98-100.

\section{Библиографический список}

1. Анализ эффективности геолого-технических мероприятий / Р.Р. Рамазанов, К.А. Харламов, И.И. Летко, Р.А. Марценюк // Нефтяное хозяйство. - 2019. - № 6. - С. 62-65. DOI: $10.24887 / 0028-2448-2019-6-62-65$

2. Иктисанов В.А., Сахабутдинов Р.3. Оценка технологической эффективности методов интенсификации добычи нефти и увеличения нефтеотдачи при помощи анализа динамики добычи // Нефтяное хозяйство. - 2019. - № 5. - С. 72-76. DOI: 10.24887/0028-2448-2019-5-72-76

3. Борхович С.Ю., Пчельников И.В., Натаров А.Л. Формирование критериев подбора скважин для проведения геологотехнических мероприятий // Нефтяное хозяйство. - 2018. - № 4. - С. 80-83. DOI: $10.24887 / 0028-2448-2018-4-80-83$

4. Распопов А.В., Новокрещенных Д.В. Анализ результатов применения методов интенсификации на карбонатных коллекторах месторождений Пермского края // Вестник Пермского национального исследовательского политехнического университета. Геология. Нефтегазовое и горное дело. - 2014. - № 10. C. 73-82. DOI: 10.15593/2224-9923/2014.10.7

5. Зейгман Ю.В., Сергеев В.В., Аюпов Р.Р. Классификация физико-химических методов интенсификации добычи нефти по механизму воздействия на пластовую систему // Геология, геофизика и разработка нефтяных и газовых месторождений. - 2017. - № 1. C. $50-53$.

6. Новокрещенных Д.В., Распопов А.В. Эффективность реализации технологии радиального бурения и матричных кислотных обработок карбонатных коллекторов месторождений Пермского края // Нефтяное хозяйство. - 2016. - № 4. - С. 118-121.

7. Мордвинов В.А. Механизм воздействия соляно-кислотных растворов на карбонатный коллектор // Нефтяное хозяйство. - 2011. № 1. - С. 44-46.

8. Определение оптимальной скорости закачки кислотных составов по результатам исследований на кернах / Г.П. Хижняк, И.Н. Пономарева, А.М. Амиров, В.Н. Глущенко // Нефтяное хозяйство. - 2014. - № 6 . C. $52-54$.

9. Закиров Т.Р., Никифоров А.И. Моделирование кислотного воздействия на нефтяные пласты при заводнении // Нефтяное хозяйство. -2012 . - № 6. - С. 62-65.

10. Modeling and simulation of wormhole formation during acidization of fractured carbonate rocks / P. Liu, J. Yao, G.D. Couples, 
J. Ma // Journal of Petroleum Science and Engineering. - 2017. - Vol. 154. - P. 284-301. DOI: 10.1016/j.petrol.2017.04.040

11. Towards a better understanding of wormhole propagation in carbonate rocks: linear vs. radial acid injection / X. Qiu, G. Aidagulov, M. Ghommem, E. Edelman // Journal of Petroleum Science and Engineering. - 2018. - Vol. 171. - P. 570-583. DOI: $10.1016 /$ j.petrol.2018.07.075

12. К вопросу выбора технологии кислотного воздействия для интенсификации добычи нефти / Ю.В. Зейгман, А.В. Лысенков, В.В. Мухаметшин, Ш.Х. Султанов // Геология, геофизика и разработка нефтяных и газовых месторождений. - 2017. - № 6. - С. 44-50.

13. Исследование кислотного воздействия с применением потокоотклонителей на карбонатные коллекторы месторождения имени Р. Требса / С.А. Вахрушев, А.Е. Фоломеев, Ю.А. Котенев, Р.М. Набиуллин // Нефтяное хозяйство. - 2016. - № 4. - С. 112-117.

14. Системный подход к кислотным обработкам призабойных зон скважин / И.М. Насибулин, Л.А. Корнильцев, Г.И. Васясин, Б.А. Баймашев // Нефтепромысловое дело. 2009. - № 2. - C. 21-26.

15. Shirazi M.M., Ayatollahi S., Ghotbi C. Damage evaluation of acid-oil emulsion and asphaltic sludge formation caused by acidizing of asphaltenic oil reservoir // Journal of Petroleum Science and Engineering. - 2019. - Vol. 174. - P. 880-890. DOI: $10.1016 /$ j.petrol.2018.11.051

16. Location and magnitude of formation damage due to iron precipitation during acidizing carbonate rocks / A.I. Assem, H.T. Kumar, H.A. Nasr-El-Din, C.A. De Wolf // Journal of Petroleum Science and Engineering. - 2019. - Vol. 179. - P. 337-354. DOI: $10.1016 /$ j.petrol.2019.04.073

17. Ituen E., Mkpenie V., Dan E. Surface protection of steel in oil well acidizing fluids using L-theanine-based corrosion inhibitor formulations: experimental and theoretical evaluation // Surfaces and Interfaces. - 2019. - Vol. 16. - P. 29-42. DOI: $10.1016 /$ j.surfin.2019.04.006
18. Finšgar M., Jackson J. Application of corrosion inhibitors for steels in acidic media for the oil and gas industry: a review // Corrosion Science. - 2014. - Vol. 86. P. 17-41. DOI: 10.1016/j.corsci.2014.04.044

19. Глущенко В.Н. Функциональная роль ПАВ в кислотных составах // Геология, геофизика и разработка нефтяных и газовых месторождений. - 2008. - № 2. - С. 27-35.

20. Prospective acid microemulsions development for matrix acidizing petroleum reservoirs / R.T.R. Carvalho, P.F. Oliveira, L.C.M. Palermo, A.A.G. Ferreira // Fuel. - 2019. - Vol. 238. P. 75-85. DOI: 10.1016/j.fuel.2018.10.003

21. Комплексный подход к разработке дизайна кислотных обработок скважин месторождения им. Р. Требса / А.Е. Фоломеев, С.А. Вахрушев, А.Р. Шарифуллин, Л.Е. Ленченкова // Нефтяное хозяйство. - 2014. - № 8. C. $72-75$.

22. Комплексный подход к выбору оптимального кислотного состава для стимуляции скважин в карбонатных коллекторах / Р.Я. Харисов, А.Е. Фоломеев, Г.Т. Булгакова, А.Г. Телин // Нефтяное хозяйство. -2011 . - № 2. - С. 78-82.

23. Фоломеев А.Е., Вахрушев А.С., Михайлов А.Г. Об оптимизации кислотных составов для применения в геологотехнологических условиях месторождений ОАО АНК «Башнефть» // Нефтяное хозяйство. - 2013. - № 11. - С. 108-112.

24. Совершенствование технологии кислотных обработок / А.А. Хакимов, Р.И. Саттаров, А.В. Качурин, А.В. Акимкин // Нефтяное хозяйство. -2012 . - № 3. - С. 54-55.

25. Garrouch A.A., Jennings A.R. A contemporary approach to carbonate matrix acidizing // Journal of Petroleum Science and Engineering. - 2017. - Vol. 158. - P. 129-143. DOI: $10.1016 /$ j.petrol.2017.08.045

26. Насибулин И.М., Мисолина Н.А., Баймашев Н.А. Современные представления о влиянии геологических факторов, определяющих процесс взаимодействия кислотных растворов с карбонатной породой // Геология, геофизика и разработка нефтяных и газовых месторождений. 2011. - № 3. - С. 56-61. 
27. Одинцова Ю.В. Влияние фильтрационно-емкостных свойств и пластовых условий на эффективность кислотных обработок карбонатного пласта // Газовая промышленность. - 2012. - № 6. - С. 38-40.

28. Анализ факторов, влияющих на эффективность соляно-кислотных обработок / Н.Г. Ибрагимов, Р.Г. Заббаров, А.М. Даминов, Р.А. Козихин // Нефтяное хозяйство. - 2014. № 1. - C. 70-71.

29. Karimi M., Shirazi M.M., Ayatollahi S. Investigating the effects of rock and fluid properties in Iranian carbonate matrix acidizing during pre-flush stage // Journal of Petroleum Science and Engineering. - 2018. - Vol. 166. P. 121-130. DOI: 10.1016/j.petrol.2018.03.002

30. Modelling temperature-influenced acidizing process in fractured carbonate rocks / G. Ma, Y. Chen, Y. Jin, H. Wang // International Journal of Rock Mechanics and Mining Sciences. - 2018. - Vol. 105. - P. 73-84. DOI: $10.1016 /$ j.ijrmms.2018.03.019

31. Мартюшев Д.А. Лабораторные исследования кислотных составов для обработки коллекторов, характеризующихся различной карбонатностью и структурой пустотного пространства горных пород // Известия Томского политехнического университета. Инжиниринг георесурсов. 2018. - T. 329, № 4. - С. 6-12.

32. Традиционные и прецизионные методы изучения порового пространства нефтеносных коллекторов / Р.Х. Сунгатуллин, Р.Р. Исламова, Р.И. Кадыров, Г.М. Сунгатуллина // Нефтяное хозяйство. - 2017. - № 11. - С. 89-91. DOI: $10.24887 / 0028-2448-2017-11-89-91$

33. Определение остаточной водонасыщенности пород-коллекторов методом рентгеновской томографии / И.В. Язынина, Е.В. Шеляго, А.А. Абросимов, Н.Е. Грачев // Нефтяное хозяйство. - 2018. - № 3. - С. 38-42. DOI: $10.24887 / 0028-2448-2018-3-38-42$

34. X-ray microtomography of hydrochloric acid propagation in carbonate rocks / A.C. Machado, T.J.L. Oliveira, F.B. Cruz, R.T. Lopes // Applied Radiation and Isotopes. - 2015. - Vol. 96. - P. 129-134. DOI: $10.1016 /$ j.apradiso.2014.10.027
35. Numerical simulation and X-ray imaging validation of wormhole propagation during acid core-flood experiments in a carbonate gas reservoir / A. Safari, M.M. Dowlatabad, A. Hassani, F. Rashidi // Journal of Natural Gas Science and Engineering. - 2016. - Vol. 30. P. 539-547. DOI: 10.1016/j.jngse.2016.02.036

36. Carbonate aciding: modeling, analysis, and characterization of wormhole formation and propagation / M. Ghommem, W. Zhao, S. Dyer, X. Qiu // Journal of Petroleum Science and Engineering. - 2015. - Vol. 131. - P. 18-33. DOI: $10.1016 /$ j.petrol.2015.04.021

37. Porous media investigation before and after hydrochloric acid injection on a pre-salt carbonate coquinas sample / A.C. Machado, A.P. Teles, A. Pepin, N. Bize-Forest // Applied Radiation and Isotopes. - 2016. - Vol. 110. - P. 160-163. DOI: 10.1016/j.apradiso.2016.01.005

38. Dong K., Zhu D., Hill A.D. The role of temperature on optimal conditions in dolomite acidizing: an experimental study and its applications // Journal of Petroleum Science and Engineering. - 2018. - Vol. 165. - P. 736-742. DOI: $10.1016 /$ j.petrol.2018.03.018

39. An experimental study on acid-rock reaction kinetics using dolomite in carbonate acidizing / H. Yoo, Y. Kim, W. Lee, J. Lee // Journal of Petroleum Science and Engineering. - 2018. - Vol. 168. - P. 478-494. DOI: $10.1016 /$ j.petrol.2018.05.041

40. Zhang K., Zhu X.K., Yan B. A refined dissolution method for rare earth element studies of bulk carbonate rock // Chemical Geology. - 2015. - Vol. 412. - P. 82-91. DOI: 10.1016/j.chemgeo.2015.07.027

41. Захарян А.Г., Мусин Р.М., Цимич М. Анализ эффективности физико химических методов увеличения нефтеотдачи пластов на объектах ОАО «НК “Роснефть”»// Нефтяное хозяйство. -2015 . - № 8. - С. 58-59.

42. Ибрагимов Н.Г., Мусабиров М.Х., Яртиев А.Ф. Опыт промышленной реализации импортозамещающих технологий интенсификации добычи нефти в ПАО «Татнефть» // Нефтяное хозяйство. - 2015. - № 8. C. $86-89$. 
43. Выявление критериев успешного применения соляно-кислотных обработок по пластам окского надгоризонта СорочинскоНикольского месторождения / В.В. Фирсов, М.А. Кузнецов, А.Ю. Попов, Д.К. Сагитов // Геология, геофизика и разработка нефтяных и газовых месторождений. - 2011. - № 2. C. 70-76.

44. Мартюшев Д.А., Пономарева И.Н. Исследование особенностей выработки запасов трещинно-поровых коллекторов с использованием данных гидродинамических исследований скважин // Нефтяное хозяйство. - 2017. - № 10. - C. 102-104. DOI: $10.24887 / 0028-2448-2017-10-102-104$
45. Черепанов С.С., Мартюшев Д.А., Пономарева И.Н. Оценка фильтрационноемкостных свойств трещиноватых карбонатных коллекторов месторождений Предуральского краевого прогиба // Нефтяное хозяйство. 2013. - № 3. - С. 62-65.

46. Пономарева И.Н. К обработке кривых восстановления давления низкопродуктивных скважин // Нефтяное хозяйство. - 2010. - № 6. C. $78-79$.

47. Ерофеев А.А., Пономарева И.Н., Мордвинов В.А. К определению пластового давления при гидродинамических исследованиях скважин в карбонатных коллекторах // Нефтяное хозяйство. - 2011. - № 4. - С. 98-100.

Please cite this article in English as:

Novikov V.A., Martyushev D.A. Acid treatment of carbonate deposits at the Perm Region oil fields. Perm Journal of Petroleum and Mining Engineering, 2020, vol.20, no.1, pp.72-87. DOI: 10.15593/2224-9923/2020.1.7

Просьба ссылаться на эту статью в русскоязычных источниках следующим образом:

Новиков В.А., Мартюшев Д.А. Опыт применения кислотных составов в карбонатных отложениях нефтяных месторождений Пермского края // Вестник Пермского национального исследовательского политехнического университета. Геология. Нефтегазовое и горное дело. - 2020. - T.20, №1 - C.72-87. DOI: 10.15593/2224-9923/2020.1.7 